\title{
Legal Ethics and Professionalism
}

Substantial numbers of citizens are disaffected with the entire apparatus of the law. In recent years commentators have begun to make the connection between this disaffection and the failure of the legal profession to make recourse to the law possible for the poor and much of the middle class. ${ }^{1}$ For the poor or otherwise disadvantaged, the law often appears exploitative rather than protective because they cannot command legal services equivalent to those of the rich. 2 For the middle class, the law is often so cumbersome and expensive that it seems poorly designed for the practical resolution of disputes. ${ }^{3}$

As one response to the perceived crisis in legal services, the organized bar as well as some of its critics have focused attention on the incidence of "unethical" behavior occurring especially among solo practitioners. But fundamental disagreement has arisen over whether the relation of unethical conduct to failure of service is one of cause or effect. The $A B A$ has regarded deviance from the profession's code of ethics as at least one cause of the mounting criticism of the organized bar, and has therefore resorted to clarifying and enforcing the code as its primary response to the crisis in legal services. ${ }^{4}$ Several leading commentators

1. The legal profession's critics include Associate Justice William J. Brennan, Jr. who has indicted the legal profession for the "obsolescence" of its "code of cthic and institutions" in our time of "social upheaval." Brennan, The Responsibilities of the Legal Profession, in The PaTH of THE LAW From 1967, at $91-92$ (A. Sutherland ed. 1969). See also Nader, Crumbling of the Old Order-Law Schools and the Law Firms, Trie NEw REPUbLIC 20 (Oct. 11, 1969); REPORT OF THE AMIERICAN ASSEMIBLY, LAW AND THE CiLARGING SOCIETY 1 (1968); Rostow, The Lawyer and His Client (Alexander F. Morrison Foundation Lecture for 1961) (part 1) 48 A.B.A.J. I (1961); W. STRINGFellow, MY PEople Is TIIE ENEMY 54 (1964) [hereinafter cited as STRINGFeliow].

2. Theodore Voorhees, past president of the National Legal Aid and Defender Association, has written that, to poor people, the "law" is "a vague and misunderstood force that seems always opposed to the poor: justice is a concept beyond comprehension." Voorhees, The OEO Legal Service Program: Should The Bar Support It?, 53 A.B.A.J. 23. See also REPORT OF THE NATIONAL ADVISORY COMMISSION ON CIVIL DISORDERS (1963); SmINCFELLOW, supra note 1; U.S. Departarent of Heatth, EDucation, and Telesse, Confenence Procefolings, The Extension of legal Services to the Poor, Address of Nicholas katzeridici 9, 13-14 (1964) [hereinafter cited as CoNference Procerdincs].

3. E. CheATHaM, A LAWYER WHEN NEEDED 59-86 Charpentier Lectures (1963) fhereinafter cited as Creathani]; Note, Providing Legal Services for the Middle Class in Civil Matters: The Problem, the Duty, and a Solution, 26 U. Prr. L. REv. 811 (1965). The primary focus in this Note will be on the function of law and of lawjers in providing civil remedies for wrongs suffered. This emphasis stems from an appreciation of the different considerations operative in the criminal context and from the fact that the actual and potential contact of citizens with the law is overwhelmingly made up of civil matters. See genetally, CheATHAN, supta.

4. The Special Committee on Evaluation of Ethical Standards was appointed on August 14,1964 , at the request of Lewis F. Powell, Jr., then president of the American Bar Association. See ABA CODE of Professional ResponsinItrry, Preface, at $v$ (Final Draft, July 1969) [hereinafter cited as ABA CoDE]. The Special Committee completed work on the Code 
on legal ethics, on the other hand, have been highly critical of the ABA's position and have proposed as an alternative a context-oriented approach, an approach that views unethical conduct as an almost inevitable effect of certain pressures at the bar's marginal levels and therefore not reachable through uniform standards. ${ }^{5}$

This Note considers the wisdom of these alternative approaches to legal ethics as they affect the crisis in legal services. The thesis developed here is that neither of the major proposals advanced thus far can by itself be an effective antidote to the law's frequent shortcomings; both are based on a faith in professionalism which prevents the development of realistic solutions to the problem of delivering the needed quantity of legal services.

\section{I.}

For many lawyers, the practice of law is a profoundly disillusioning experience. Approximately fifty per cent of at least the metropolitan bar are solo practitioners. ${ }^{6}$ These lawyers have for the most part found unattainable the prestige and economic rewards which were their most important goals in entering the legal profession. ${ }^{7}$ Excluded from medium to large-sized law firms by hiring practices that have traditionally been restrictive along educational, racial, ethnic, and religious lines, "success" has been very difficult for blacks, for members of religious and ethnic minorities, and for sons of non-professionals. ${ }^{8}$ The inability

of Professional Responsibility during the summer of 1969 and the ABA House of Delegates passed the Final Draft on August 12, 1969.

5. See, e.g., J. CARLIN, LAwYERS ON THEIR OWN 3 (1962).

6. Approximately $53 \%$ of all lawyers in private practice are individual practitioncry. The discussion in this Note is most relevant to private practitioners in urban areas where solos comprise about $51 \%$ of the total population of lawyers. AM. BAR FoundATION, TIu' 1967 LAWYER STATISTICAL REPORT 18 (1968). For a discussion of the social structure, ethics and social control of the bar in a middle-sized community, sce J. HIANDLER, Ti1: LAIYYER AND HIS COMMIUNITY (1967).

7. J. Carlin, Lawyers on Their OWN 1-3 (1962).

Until fairly recently, writing on the sociology of the legal profession has been in a rather rudimentary state. In the last ten years, this has begun to be remedied. See, e.g., J. CAllLIN, GarLIN, LaWYERS ON TheIr OWN (1962); J. CARLIN, LAWYERS' ETHICS (1966); N. WARKOV,

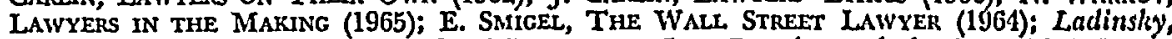
The Impact of Social Backgrounds of Lawyers on Law Practice and the Law, 16 J. LEOAt. ED. 127 (1963); Reisman, Law and Sociology: Recruitment Training and Colleagueship, 9 STAN. L. REv. 643 (1957).

8. Individual practitioners in Ladinsky's sample were more likely than firm lawyers to be from ethnic minorities $(59 \%$ of the individual practitioners, but only $10 \%$ of the firm lawyers were from families in which the father was first or second gencration American); to have a father with a manual occupation ( $30 \%$ v. $7 \%$ ); to be Catholic or Greek Orthodox $(34 \%$ v. $26 \%$ ) or Jewish ( $35 \%$ v. $6 \%$ ); and to be from Eastern or Southern Europe (50\% v. $6 \%$. Ladinsky, The Impact of Social Backgrounds of Lawyers on Law Practice and the Law, 16 J. Legal ED. 131, 137-39 (1963). See also J. Carlin, Lawyers' Ethics 28-37 (1966). 
of these lawyers to enter established firms has forced them into solo practice. And although the solo practitioner is the exemplar of the lawyer, at least in popular lore, the average income of solo practitioners in most metropolitan areas is less than half that of lawyers practicing in firms of two or more men. ${ }^{9}$ It is this large group of solo practitioners that serves the poor and much of the middle class, and its failure to perform this function effectively has led to renewed interest in the problems of "marginal practice."10

Success or failure, in the sense of the relative position of lawyers ,within the bar's income and prestige hierarchy, has long been explained by "respectable" segments of the profession exclusively in individual terms: those who lack learning or virtue become marginal lawyers.11 What has concerned the leaders of the profession about marginal practice has been the pervasiveness of "unethical" behavior at that level.12 It is the lawyer serving the poor and the middle class who is cited most often by ethics committees for advertising, ambulance-chasing and using lay intermediaries as methods of getting business ${ }^{13}$ - all in violation of the canons. Marginal practitioners also adhere less frequently to widelyheld community norms. The "shyster" lawyer who has caused so much of the public to be distrustful of all lawyers is not a member of a successful medium or large-sized firm; he is an independent operator who preys upon the poor or otherwise dependent and whose reputation represents the cumulative impact of exhorbitant fees, fraud, lack of training, lack of concern for the client, a willingness to peddle influence and to play the role of fixer/manipulator. ${ }^{14}$

The linking of "unethical" behavior to the failure of the poor and the middle class to receive legal services of an acceptable quantity and quality ${ }^{15}$ provided the impetus for translation of the bar's long-standing

9. In New York, the average net income of solo practitioners as disclosed in the 1963 IRS Statistics of Income was $\$ 7,579$. Meanwhile, lawjers practicing in firms of two or more men in New York had an average net income of $\$ 22,559$. Other representative juricdictions include: California-solo $\$ 12,114$, firm $\$ 22,707$; Illinois-solo $\$ 10,263$, firm $\$ 21,819$; Michigan-solo $\$ 8,308$, firm $\$ 23,342$; Pennsylvania-solo $\$ 9,773$, firm $\$ 20,823$. Smith \& Clifton, Income of Lawjers, 1963-64, 54 A.B.A.J. 51, 52 (1968).

10. The phrase "marginal practice" belongs to Carlin, who uses the words to denote those practitioners discussed at TAN 6.9.

11. See, e.g., Smith, Canon Two: "The Lawyer Should Assist the Legal Profession in Performing Its Duty To Make Legal Services Available," 48 TExAS L. REv. 285, 290 1970).

12. Hazard, Foreword, in J. CarLin, Laivyers' Ethics (1960).

13. T. Carlin, Lawyers' Ethics $41-65$ (1960).

14. See genetally J. CarLIN, LAwYers' Ethics (1960).

15. At its inception, the Committee on Re-evaluation of the Canons of Professional Ethics took as part of its responsibility a "[c]areful reevaluation [of the cxtent to which departures from high ethical standards and lapses in strict enforcement [were] related to the content of the canons." [Emphasis supplied] American Bar News, Sept. 15, 1964, at 2, col. 1. As the Committee's work developed, however, it became apparent that the concern 
concern with unethical behavior among marginal practitioners into a program aimed at clarifying the profession's code of ethics and increasing the severity of its sanctions. ${ }^{16}$ But the ABA's emphasis on the Code of Professional Responsiblity as its major weapon in dealing with the problem of inadequate legal services indicates that it is more concerned with improving the quality of legal services than with increasing the quantity of services. Directed against conduct thought detrimental to the production of high quality services, the Code apparently assumes that if individual lawyers perform the tasks they undertake with skill and care, the legal profession's responsibility to society can be metor at least public criticism of the lawyer defused. ${ }^{17}$

The marginal practitioners who are principally affected by the Bar Association's strategy in this regard generally support as a class the strengthening of the profession's code of ethics.18 They regard it as a defensive bulwark against competition from other attorneys and from lay groups. ${ }^{19}$ Intra-professional competition has long been officially frowned on by the bar, ${ }^{20}$ but despite measures proscribing competitive devices as "unethical," competition continues in only slightly muted forms. Meanwhile, competition from lay groups is an even more threatening fact in the life of the marginal practitioner-banks, trust com. panies, title companies, savings and loan associations, tax companies, accountants and real estate brokers successfully attract many of the clients and much of the work that the marginal practitioner regards as his own..$^{21}$ Caught up in a fierce struggle for professional existence, the marginal practitioner relies on the code of ethics to disarm his opponents.

with content was not in the direction of a reevaluation of the basic principles announccd in the Canons of Professional Ethics, but with their ineffectiveness in acting as guides for behavior and as a basis for disciplinary action.

16. Wright, The New Code of Professional Responsibility, in The Path of the Lat From 1967, at 121 (A. Sutherland ed. 1968); Armstrong, $A$ Re-evaluation of the Canons of Professional Ethics, $A$ Practitioner and Bar Association Viewpoint, 93 TENN. L. REv. 154 (1966); Cheatham, Availability of Legal Services: The Responsibility of tho Indi. vidual Lawyer and of the Organized Bar, 12 U.C.L.A. L. REv. 438 (1965); ProfessionnL RESPONSIBILITY: REPORT OE THE JOINT CONEERENCE, 44 A.B.A.J. 1159, 1160 (1958).

17. See, e.g., American Bar News, Sept. 1964 at 1, col. 1; Tucker, The Large Law Firm, Considerations Concerning the Modernization of the Canons of Professional Ethics, 1065 Wis. L. REv. 344, 350 (1965); Weckstein, Maintaining the Integrity and Compatcuco of the Legal Profession, 48 TEXas L. REV. 267, 268 (1970).

18. J. Carlin, LAWYers' ETHics 70 (1966).

19. In addition to seeing the code as a defensive mechanism, the marginal practitioner often regards the existence of the code and of the ritualistic fictions implicit in it as cssential to his self-image as a professional. See Schuckman, Ethics and Legal Ethics: T\%/o Propriety of the Canons as a Group Moral Code, 37 GEo. WAstl. L.. REv. 244, 245 (1968).

20. See Canons of Professional Ethics, Canons 10 (acquiring interest in litigation), 12 (minimum fees), 27 (advertising), 28 (solicitation), 33 (use of partnership names), 49 (ap. proved last lists), 45 (specialization). See also ABA CoDE, Canon 2, at 13.43.

21. J. CarLIN, LAWYERS ON THEIR OWN 41-116 1962). 
Thus the code of ethics is regarded as serving the valid interests of both the marginal and elite segments of the bar. But for a number of reasons, the approach embodied in the Code has slight chance either of lessening the incidence of "unethical" conduct or of improving the quantity of legal services available to the poor and the middle class.

II.

Jerome Carlin, in ground-breaking sociological studies of private practitioners in Chicago ${ }^{22}$ and New York Gity, ${ }^{23}$ has been the most influential critic of the ABA's approach to the problems of unethical conduct and inadequate service. He has suggested that the ineffectiveness of the ABA's old Canons of Professional Ethics ${ }^{24}$ can be traced to the tendency of both the dominant segments of the profession and of the marginal practitioners "to conceive of professional norms as existing independent of the social and organizational context within which they are meant to operate."25 This is unfortunate, Carlin argues, because the ability of the marginal practitioner to adhere to the profession's code of ethics is determined in large part by the "pattern of opportunities and pressures to which he is exposed in his practice ...."20 The uncertain and nonrepeating character of his clientele, the necessity to combat the unrestrained competition of laymen, the corrupting influence of the lower courts and agencies of government with which he deals, the non-supportive nature of his colleague group, and the condescension of the relatively more successful lawyers who regard themselves as superior to him socially and professionally, all contribute to a deep-seated dissatisfaction with the law as a profession and to a willingness to violate at least the letter of the rules set out by the "elite" who drafted the Code. ${ }^{27}$

Carlin does not suggest that the profession's code of ethics should be

22. J. CarLin, LAwYERS ON Their OWN (1962).

23. J. CariIn, LAwyers' Ethics (1966).

24. Although both of Carlin's studies were undertaken in reference to the old Canons of Professional Ethics, the form of his analysis and his findings are directly relemant to a discussion of the new Code of Professional Responsibility. For a discussion of specific canons of the new Code in light of Carlin's theory of legal ethics, see pp. 1184-86 infra.

25. J. CARLin, Lawyers' Ethics 6 (1966).

26. Id. 7.

27. J. CARLIN, LAwYERS ON TheIr OWN 168-200 (1962). With varying degrees of selfconsciousness, an actor may depart from established ethical norms while justifying such departure to himself and allowing no sense of inconsistency to develop in his affirmation of the binding effect of the code on other individuals. D. MATZA, DELNQuENicy AND DRIFT, 60-62 (1964). See also, J. PIRE, BEyOND THE LAW I4-16 (1969). To a great extent, this technique appears to have been operative in the ethical transgressions of marginal practitioners. J. CarLIN, LATYYER' ETHOS 81-82 (1966). 
scrapped entirely, but he does argue that the bar will be forever unsuccessful in its attempt fundamentally to affect "unethical" behavior by rule-making; ${ }^{28}$ even the quality goals of leaders of the bar can be achieved only if a concurrent effort is launched greatly to expand the demand for legal services by those who currently seek other means to resolve their problems. Only such a stimulation of demand can neutralize the economic pressures toward "unethical" behavior. Carlin proposes measures such as government subsidy, pre-paid insurance plans, the neighborhood law office, and group legal practice "to increase and stabilize the demand for legal services," thereby enhancing the economic security of marginal practitioners and eliminating the temptation to indulge in unethical behavior. ${ }^{20}$

Although the Code of Professional Responsibility represents a net improvement over the sixty-one year old Canons of Professional Ethics in the latitude it allows individual practitioners in responding to variable conditions of practice, the new Code still contains numerous provisions that are at odds with Carlin's suggestions. And since the Code's enactment by the $A B A$, these provisions have received the most sustained criticism. ${ }^{30}$

For example, the Code provides that "[a] lawyer who has given unsolicited advice to a layman that he should obtain counsel or take legal action shall not accept employment resulting from that advice ...."'nt Despite the general principle stated in Canon Two that "A Lawyer Should Assist the Legal Profession in Fulfilling Its Duty To Make Legal Counsel Available," 32 no real concession is made in this proscription to variable conditions of the lawyer's practice. ${ }^{33}$ And although

28. The fallacy of normative determinism is explored in Blake \& Davis, Norms, Values and Sanclions, in HANDBOOK OF MODERN SOcrologY (R. Faris ed. 1964):

The blueprint theory of society does not fit the facts of social existence. Socicties as wo

know then are highly active and dynamic, filled with conflict, striving, deccit, cunning,

Behavior in a given situation tends to be closely related to that situation, to be strongly

affected by individual interests, to be unpredictable from a knowledge of the norms alone.

Id. 464.

29. J. Carlin, Lawyers' Ethics 181 (1966).

30. Joost, Professional Responsibility, The Missing Dimension, Trat 20 (Junc/July 1969); Wallace, The Code of Professional Responsibility-Legislated Irrelevance?, 48 TEXAS L. REv. 311 (1970).

31. A.B.A. CODE, DR 2-104 (A). See also DR 2-103 (A), which specifics that "A lawyer shall not recommend employment, as a private practitioner, of himself, his partner, or as. sociate to a non-lawyer who has not sought his advice regarding employment of a lawycr."

32. A.B.A. CODE, Canon 2, at 13. Recognition by the American Bar Association of an affirmative duty in this regard represents a significant departure from the Canons, which did not specifically provide for such an obligation. According to the ABA Ethics Com. mittee, however, such a duty was implicit in the old Canons and was binding on all mem. bers of the profession. ABA Comm. on Professional Ethics, Opinion No. 320 (1968).

33. The Code makes a limited concession to some forms of institutional advertising: 
enormous differences exist in the ability of prospective clients to recognize legal problems and to gain access to the legal system, ${ }^{34}$ it is as unethical for lawyers to advertise or solicit in Harlem as it is on Wall Street.

To take a further example, the Code permits group service arrangements ${ }^{35}$ "only in those instances and to the extent that controlling constitutional interpretation at the time of the rendition of the services requires the allowance of such legal service activities . . . " Nowhere in the Code is there a hint of the desirability of contextual variation or of a willingness to engage in the balancing of interests apparently re-

Examples of permissible activities include preparation of institutional advertisements and professional articles for lay publications and participation in seminars, lectures, and civic programs. But a lawyer who participates in such activities should shun personal publicity.

One of the means by which the bar has attempted to alert people of moderate micans to the legal services that are available is the lawyer referral scrvice. Sec, ABA CODE, EC 2-15, at 16. The lawyer referral service involves the use of local attornejs who have agreed to provide counseling at a moderate fee to prospective clients referred to them. These clients generally contact the service office in response to a program of public education undertaken by the local bar. As of 1965, approximately 220 referral services were in operation across the country, involving some 17,000 lawyers and 150,000 clients per year. AfeAlpin, The Bar Faces Forward, 51 A.B.A.J. 548 (1965).

The lawyer referral service has proved to be a useful device in alleviating the legal scrvice void for people of moderate means, but it is questionable that its continued use or expansion can provide any long-range solution to the legal service needs of the middle class. It is even more doubtful whether such services can have an appreciable effect in making legal services more accessible to the poor. At least three reasons for this an be identified: (1) lawyer referral services have not received sufficient support from local bar associations to ensure their success; (2) such plans do not eliminate the need for specialization or continuing legal services at moderate prices; and (3) referral services conducted by the bar do litele to reduce the impersonality or randomness in lawyer selection that is implicit in alternatives such as group legal services. Certainly, the continued growth of group legal services and the persistence of unauthorized practitioners indicates that lawjer referral services have been less than unqualified successes. On the referral service alternative, see Christensen. Lawyer Referral Service: An Alternative to Laj-Group Legal Services, 12 U.C.L.A. L. REv. (1965); Madden \& Christensen, Lawyer Referral Service: A Sensible Approach 10 a Difficult Problem, 49 A.B.A.J. 965 (1963); Gallantz, Lawyer Referral, A Brief Hislory, 45 J. AAr. JUD. Soc. 306 (1962).

34. [I]t may be suggested that traditional notions about solicitation do not fit comfortably the plight of the poor and the alienated. Programs of consumer and slum. tenant education may generate 'legal business', to be sure, but this is a vorld away from the evils against which the relevant canons were drawn.

Frankel, Experiments in Serving the Indigent, 51 A.B.A.J. 460, 463 (1963). Sec also Zcitz, Survey of Negro Attitudes to Law 19, cited in Carlin \& Howard, Legal Represenlation and Class Justice, 12 U.C.L.A. L. REv. 381, 430 (1965).

35. The literature on group legal services is considerable. Many of the articles on the subject deal primarily with the constitutional issues involved: sec, c.g., Comment, 63 Colun. L. Rev. 1502 (1963); Note, Group Legal Services, 79 HARv. L. REv. 416 (1965). Others go beyond the purely legal questions and treat a broader range of issues: see, e.g., Zimroth, Group Legal Services and the Constitution, 76 YALE L.J. 960 (1967); Cheatham, $A$ Lauyer When Needed: Legal Services for the Middle Classes, 63 Colua. L. REv. 973 (1963); Schwartz, Foreword: Group Legal Services in Perspective, 12 U.C.L.A. L. REv. 279 (196j). The controversy over group legal services and the relevant literature is placed in perspective in an excellent monograph by Barlow Christensen of the American Bar Foundation: Group LEGAL SERVICES (1967).

36. ABA CODE, DR 2-103 (D) (5), at 25. 
quired by the Supreme Court in recent cases. ${ }^{37}$ As with solicitation, the Code abjures any responsibility for allowing experimentation with group arrangements, ${ }^{38}$ even in situations where the potential of such arrangements for meeting the public's need for legal services seems stronger than their potentially negative effects.

The basic flaw in the ABA's Code of Professional Responsibility from the perspective of its most influential critics, then, lies in the monolithic and inflexible character of its provisions. With only limited exceptions, the Code incorporates the flaws that Carlin perceived in the Canons of Professional Ethics: the Code relies too heavily on the efficacy of norms as instruments of social control and does not pay sufficient attention to variability in the contexts in which those norms are meant to operate. ${ }^{30}$ The effect of this must be to inhibit the structural changes that are the necessary prerequisites to any significant extension of legal services and to the rejuvenation of presently marginal practice.

\section{III.}

The contextual approach to the problems of marginal practice has substantial intuitive appeal. The legal profession should regard a certain amount of diversity in modes of delivery of legal services as a source of strength rather than of weakness. A cursory examination of professions reveals that all, to some degree, "consist of a loose amalgamation of segments," 40 and that their dynamic quality and ability to adjust to changing conditions derives from this heterogeneity. But because the dominant segments of the bar have no contact with the harsh

37. N.A.A.C.P. v. Button, 371 U.S. 415 (1963); Brotherhood of Trainmen v. Virginia ex rel. Virginia State Bar, 377 U.S. 1 (1964); United Mine Workers of America, District 12 v. Illinois State Bar Ass'n, 389 U.S. 217 (1967). Beginning with the Button case, the Supreme Court has begun to step into the hitherto sanctified chambers of the legal profession to indicate that changing conditions have rendered the traditional structure of the profession constitutionally deficient in some respects. The cumulative effect of Button and its progeny is to signal a new departure in constitutional adjudication in situations of conflict between individual rights and the traditional prerogatives of the bar: the Court has "served notice that no longer [is] the practice of law to be considered a 'privilege,' to be treated by exclusive reference to the professional standard without regard to the other social interests which might be involved." Schwartz, Foreword: Group Legal Services in Perspective, 12 U.C.I.A. L. REv. 279, 283 (1965).

38. ABA CODE, DR 2-103 (D) (5), at 25.

39. See Schuckman, supra note 19 , at $244,256-57$, for the proposition that a good measure of contextual variability is built into the profession's code of ethics $s+b$ rosa, $i, c$, by virtue of what it does not cover. Neither the Canons nor the Code prescribe the forms of advertising and solicitation most often undertaken by the elite, for cxample, entertainment by clients, use of clubs. See also E. SMIGel, THE WALl STREeT LAWYER 293.94 (1964), for a view of the Wall Street lawyer as an organization man whose professional life secms in con. flict with many of the principles of the Code.

40. Bucher and Strauss, Professions in Process, 66 As. J. of Soc. 325, at 833 (1961). 
realities of marginal practice, and because they have an inadequate appreciation of the public's need for certain kinds of services, the reforms Carlin suggests are blocked.41

The organized bar has thus far regarded external pressures for change, such as mandates issuing from the Supreme Court, 12 as misguided efforts tending to destroy the functional independence of the legal profession. In reality, Carlin charges, the sum of the bar's response, at least as late as 1964, suggests that "it may be less concerned with extending legal services than with preserving its monopolistic control over the provision of such services." 43

In spite of the aura with which the ABA has attempted to surround it, the Code of Professional Responsibility is undeniably of political and economic rather than spiritual derivation. ${ }^{42}$ In any code of ethics, some norms, relating chiefly to truthfulness and fair dealing, can be codified without much attention to differences in conditions of practice, because all members of the community, professional and other, are expected to abide by these values. Other provisions of the ABA's Code of Professional Responsibility, however, respond to demands within the group itself and do not find a clear referent in community standards. ${ }^{45}$ Such norms are not immutable in the sense of having a life apart from the segment or segments of the bar responsible for their formulation. ${ }^{46}$

Those in control of the legal profession at any point in time will be sorely tempted to use the code of ethics as a weapon to perpetuate their position of control, or to prevent even small shifts in the balance of power within the profession. ${ }^{47} \mathrm{~A}$ large element of this motive appears to have been at work in the codification of the bar's resistance to group legal services. ${ }^{48}$

As individuals and without regard to their respective positions within the professional hierarchy, members of a profession also acquire a vested

41. J. Carlin, Lawyers' Ethics 37, $181-82$ (1966).

42. Cases cited note 37 supra.

43. J. Cardin, Laivyers' Ethics 180 (1966).

44. For an account of the political accomodations and changes in Canon Tro from the Preliminary to the Final Draft, see Nahstoll, Limitations on Group Legal Services Arrangements under the Code of Professional Responsibilily, DR 2-103 (D) (5); Stale Wine in New Bottles, 48 TEXAs L. REv. 334, 343-45 (1970).

45. See, e.g., ABA CODE, DR 2-102 (professional notices, letterheads, offices and lay lists): DR 2-107 (division of fees among lawyers): DR 3-103 (forming a partnership with a non-lawyer): DR 8-102 (statements concerning judges and other adjudicatory officers).

46. Schuckman, supra note 19, at 257-58.

47. Cf. Lynn, Introduction to the Issue, Symposium, "The Professions," 92 Dardars 649, 652, (1963).

48. See Nahstoll, supra note 58 , at 348 n. 35 . 
interest in the status quo that militates against a highly permissive code of ethics. If adopted, Carlin's proposals to allow group legal services (with their potential for economy and efficiency) and to liberalize rules regarding advertising would produce increased intra-professional competition; practitioners will inevitably regard such a development as presenting a dangerous threat to their own means of livelihood.40 Whatever the merits of proposed changes in the Code, the profession's interest in certain forms of practice keeps the Code as it is. The Code's restrictions on the use of advertising ${ }^{50}$ and its generally negative approach toward specialization ${ }^{51}$ are examples of this tendency at work.

Given the existence of these interests and the high degree of stratification that already exists within the legal profession, there is a certain inconsistency in Carlin's suggestion that fundamental changes can be brought about by the bar's tinkering with its code of ethics. Carlin appears to regard the bar's professionalism as a salutary given ${ }^{62}$ or as an end earnestly to be sought after, and his analysis consequently takes place within the confines of a professional model..$^{53}$ His inattentiveness

49. The bar's attempt to restrict entry into the profession may derive from some of the same sort of motivations, especially to provide higher incomes for "authorized" practi. tioners. See generally, Johnstone, The Unauthorized Practice Controversy-A Strtigglo Among Power Groups, 4 KaN. I. REv. 1, 5 (1965).

50. See Wilbur, Adverlising, Solicitation, and Legal Ethics, 7 VAND. L. REV. 677, 684 (1954): "Perhaps, too, underlying the condemnation of solicitation is the idea that cquallty of opportunity will more nearly prevail in the profession when all are subject to the same restrictions." See also Armstrong, $A$ Re-evaluation of the Canons of Professional Elhics, $A$ Practitioner and Bar Association Viewpoint, 33 TENN. L. Rev. 154, 161 (1966): "Unless universal standards are maintained, the ethical lawyer, as $I$ have said, will be placcd at an economic disadvantage ... [and he] will lose the thing which is most important to himhis own high opinion and his own high standards of his profession."

51. ABA CODE, DR 2-105 (A) (4), at 27. For the thesis that the profession's conservatism in this area may be an outgrowth of the hesitancy of the large firms to allow the diffusion of the advantages presently accruing to them in a situation of de facto specialization, sec Wallace, supra note 30 , at 318 .

52. A number of Carlin's suggestions would tend to undermine some of the traditional indicia of professionalism. To the extent that legal services became commercialized through private advertising or that group arrangements diminish the lawyer's previous indepen. dence, they could be regarded, at least in a theoretical sense, as antiprofessional. At lcast one commentator on the Code of Professional Responsibility has seen these elements as "indeed . . . basic to the whole concept of professionalism." Smith, stipra note 11, at 286.

53. Despite the importance of professions in American socicty, writing in the ficld is still in a rudimentary state. A good introduction to the professional phenomenon is A. Garr-Saunders \& P. Wilson, The Professions (1933). Carr-Saunders \& Wilson wrote of English professional life. No comparable American study has yet appearcd. We do possess some outstanding studies of individual professions and some general studics that are less ambitious in scope than Carr-Saunders \& Wilson, includingt T. PArsons, STRuctures AND Process in MODERN SOcIETIES (1960); Symposium, The Professions, 94 DAEDAlus 647 (1963); Goode, Encroachment, Charlatanism, and the Emerging Professions: Psychology, Sociology, and Medicine, 25 AM. Soc. REv. 902 (1960); Goode, Communily Within a Community: The Professions, 22 AM. Soc. REv. 194 (1957); Mcrton, Somo Thoughts on the Professions in American Society, Brown Univ. Papers, No. XXXVII 
to non-professional solutions to the crisis in legal services and to unethical behavior derives from two assumptions: first, that many of the legal problems confronting the poor are potentially as complex as those of the rich and therefore require lawyers of as great skill; ${ }^{-5}$ and second, that the ability of the poor to compete for legal services in the open marketplace will always be seriously impaired by their chronic lack of funds. ${ }^{55} \mathrm{He}$ therefore advises that the present scope of the legal profession's monopoly should be retained intact to assure quality. Absolute ethical standards, however, should be replaced by a balancing test administered by the bar on an ad hoc basis. This balance would presumably take into account both the public's need for certain kinds of services and the profession's interest in preserving a basic uniformity in work patterns.

But if a balancing test of some sort were to be at all successful in introducing tolerance for the demands of variable conditions of practice, the leaders of the bar would have to develop a far greater sensitivity to and sympathy for the requirements of diverse clientele and work tasks than now exists. Where the true interests of the public and of the marginal practitioner are underrepresented in its administration, a system of flexible rules will produce results no different than current absolute standards of propriety. ${ }^{50}$ And as long as the elite and the marginal practitioner perceive a common interest in preventing the emergence of new forms of practice, reform as urged by Carlin will be impossible.

Even if Carlin were to be successful in liberalizing the legal profession's code of ethics, however, such a reform in the long run would very likely amount to little more than a palliative. He calls for flexibility in procedures, but concludes that a uniform level of training and a "professional" allegiance should be required of all legal personnel. Insofar as this position assumes comparable complexity of legal problems at all strata of society, it can be criticized. The contact of poor people with

(1960); Merton, The Functions of the Professional Association, 58 Axr. J. OF Nusenc 50 (1954); The Professions and Social Structure, 17 Soc. Forces 457 (1939).

54. Carlin \& Howard, Legal Representation and Class Justice, 12 U.C.L.A. L. REv. 381, 386-407 (1965).

55. Id. $428-29$.

56. It is not at all clear why the public should allow the continuation of a situation whereby the governed (marginal practitioners) have so little in common with thase who govern (the clite of the metropolitan bar). The problem with the alliance of two or more disparate groups is that at certain times the best interests of the groups are likely to confliet. Rules pertaining to solicitation provide a case in point: clite lawjers and the propertied interests they represent are generally more concerned with the cvils of solicitation than are marginal practitioners or the poor. If the poor learn of their legal rights and of the possibilities of securing representation through advertising, the advantages of landlords and businessmen may be threatened. Schucliman, supra note 19, at 265. 
the law tends to arise from landlord-tenant, consumer credit, family and criminal law matters. ${ }^{67}$ The issues in these areas are simply not as conceptually complex as are those involved in the legal problems of the rich. ${ }^{58}$ Where complexities do exist, they are often the fault of the profession itself, which out of neglect or design has allowed the proliferation of a procedural maze. ${ }^{\text {g9 }}$

Furthermore, Carlin's conclusion that the poor and middle class cannot subsidize their own legal services is also open to serious question. The increasing competitive pressures from lay agencies for the control of many of the work tasks of the marginal practitioner, and the success of these agencies despite the virulence of the bar's campaign against unauthorized practice, ${ }^{, 0}$ suggest both an unexploited market for legal services and the potential economies of specializing and routinizing those services. Despite protests from the bar, title companies continue to search and to clear titles, banks and savings and loan associations continue to close land deals using standardized forms and to set up trusts and estates, tax offices continue to process enormous numbers of individual and business returns, individual accountants and accounting firms continue to advise clients in legal matters, and estate planners continue to plan. The explanation is apparent: in the words of one commentator, "Laymen go to unauthorized practitioners who are accessible, whose charges they do not fear, and whose dependability they rely on because of connections with familiar institutions they trust." 01

The very pervasiveness of the law, especially in the lives of the poor, suggests that many legal matters are simple-requiring the services of trained intermediaries for satisfactory disposition, but intermediaries of a rather low-level skill. ${ }^{62}$ Sustained contact with the law and the insti-

57. Dolan, Where Will Ursula Go? 55 A.B.A.J. 1046 (1969); Frankel, Experiments in Serving the Indigent, 51 A.B.A.J. 460 (1965).

58. STRINGFeliow, supra note 1 , at 44.

59. The Ethical Considerations set out in Canon Eight of the Code of Professlonal Responsibility apparently recognize the criticism lodged here regarding the unnecessary prolixity of the legal system as a function of the self-interest of lawyers as a class. See, e.g., ABA CODE, EC 8-2, at 107; See also ABA CODE, EC 8-1, at 106; Professional Responsi. bility: Report of the Joint Conference, 44 A.B.A.J. 1159, 1217 (1958).

The argument that is developed in this section is that the prolixity of the law derives from too jealous guarding of work-tasks that need not-and some that should not-be performed by lawyers. Before the goals of simplifying and updating the law, which are embodied in Canon Eight, can be realized, the bar as a whole must comc to grips with the fact that full enforcement or true commitment to the canons will undermine further, at least in the short run, the economic position of many marginal practitioners.

60. J. Carlin, LAwYers ON Their OWN 157 (1962).

61. Cheatham, supra note 3, at 63-64. See also Special Committee on the Economic Condition of the BAR, RePORT, 63 A.B.A.J. REP. 390, 391 (1938).

62. Paulsen, The Legal Needs of the Poor and Family Law, in Conference Procerdincs, The Extension of Legal. Services to the POOR 19 (1964). 
tutions of government requires sustained assistance, but it is just this species of sustained, low-level assistance that traditional legal practitioners-highly trained and oriented toward discrete cases-do not supply. ${ }^{63}$ The lawyer's expertise in handling the litigative aspects of cases often results in success being measured in terms of cases won rather than in real results obtained for the individual clients. If the poor and, to a somewhat lesser extent, the middle class are to be assisted in managing their contact with the law and the various institutions of government, they must be educated to their rights and remedies, and more liberal use must be made of the talents of laymen and other professionals: social workers, marriage counselors, employment advisors, psychiatrists, welfare personnel. ${ }^{44}$

The bar's resistance to mass production techniques and competition from laymen is phrased in terms of preserving the strength of the legal profession as a viable element in our society and in terms of ensuring the quality of legal services. ${ }^{65}$ The lack of attention to quantily considerations is in some respects reminiscent of the tactics of the old vocational guilds. ${ }^{66}$ The leaders of the various guilds controlled entry into their select groups and strictly regulated activities of members. Guild members stubbornly refused to alter their methods of doing things and were highly protective of the traditional scope of the work tasks entrusted to their care. Guild organization was advocated as necessary to preserve the high quality of the goods produced and to safeguard the honor and dignity of the avocation; to the extent that the goods produced by the guilds were other than luxuries, society's unfilled demand for them could be met by a combination of charity and government subsidy. But the hold of the guilds on the economy eroded with time, for a variety of reasons, not the least of which was that the work tasks they performed came to be accomplished more efficiently by groups using methods which guilds refused to adopt, methods that made obsolete much of the elaborate learning mastered by guild members. The privileged status of the guilds could not be maintained when their reason for being evaporated.

Substantive reform in the law, as opposed to changes in the legal pro-

63. Stringfellow, supta note 1 , at 44.

64. See Address of Nicholas Katzenbach, Conference Proceronics, supta note 2, at 13-14; McAlpin, supra note 33, at 550. See also Smith \& Curran, A Study of the LazyerSocial Worker Professional Relationship, in Ax. BAR FOUNDATION RESEARCh Co:TIUnUTIONS No. 6 (1968); Sparer, Thorkelson \& Weiss, The Lay Advocate, 43 U. DET. L.J. 493 (1960).

65. B. Christensen, Group Legal Services (1967).

66. W. Gellforn, INDIVmual FreedoM AND Governamentar Restraints 118, 143-45 (1956). 
fession's code of practice, is greatly inhibited by the problem of training; far too little attempt is made in law school to instill in students either a critical faculty for spotting inherited anomalies in the law or a conception of professional responsibility that leads to an impatience with such anomalies. ${ }^{67}$ Training also reinforces the idea that legal matters are not simple, and thus provides lawyers with a rationalization for their defense of the status quo. To simplify procedures or otherwise demystify the law or to reduce the scope of the bar's monopoly might vastly expand the total demand for legal services, but it would also destroy employment opportunities for many lawyers. ${ }^{\circ 8}$ While regarded as dangerously radical by some members of the bar, Carlin's proposals for making legal services available to more people-through government subsidies, pre-paid insurance plans, group services-speak somewhat inadvertently to the bar's self-interest. Their effect would be to retain intact our often antiquated legal system, and the bar's control over that system, and would produce revenues for hitherto marginal practitioners while not stimulating a general overhaul of the profession.

Carlin's reliance on transfer payments to subsidize legal services for the poor has two obvious faults: taxing the well-to-do complicates the system and produces resentment, and securing the poor their rights through charity is inevitably degrading. ${ }^{00} \mathrm{~A}$ lowering of artificially high transaction costs through the simplification of procedures and the

67. Communication of "professional" values is often regarded as one of the nost im. portant tasks of legal education. See. e.g., Watson, Some Psychological Aspects of 'Trach. ing Professional Responsibility, 16 J. LECAL ED. 1 (1963).

68. It is infrequently the [solo practitioner's and small firm's] expertise which his clients want. But they have need of his franchise, his small part of the moriopoly which the bar still has. Further, it is usually only in the truly closed shop and pathological situations that the [solo practitioner] as a lawyer is sought. He is necded for the small claims, domestic relations and surrogates courts open only to lawyers, the personal injury cases which cannot be quickly settled and the closings which foll through.

Schuckman, supra note 19 , at 253.

69. At one point in the development of our legal system, legal aid was advanced as a panacea to remedy denial of justice to the poor. This remedy was premised on a belicf that the problems faced by the poor, being legal, required the services of an attorncy. But in retrospect, it appears that legal aid and the logic that scemed to compel it falled because of a flaw in the basic premise: because many of the tasks performed by legal aid lawyers require only low-level skills, legal aid has not proved challenging enough to prevent a quick and constant turnover among its young lawyers. MIost of the lawyers who have remaincd are aware of the intellectual and monetary sacrifices they have made and this sense of personal sacrifice has spilled over into their legal aid work. Lcgal ald clients are made painfully aware that in the area of legal services as elsewhere, they do not command attention as a matter of right; the realization of their legal rights is dependent on the incidence of societal largesse.

This situation is in marked contrast to the one which prevails in most medical ald clinics. Medical aid clinics and public health services have been successful in attracting and holding bright young doctors precisely because of the great range of unusual nicdical problems that constantly confront public health doctors. 
redefinition of the bar's monopoly would allow the market, without external supports, to apportion legal services more nearly in conformance with the true needs of poor and middle class consumers of legal services. ${ }^{70}$

IV.

The responsibility for fashioning a long-range solution to the current crisis in legal services and to the dislocations of marginal practice rests on the courts, legislatures and law schools: only these institutions have the necessary psychic distance, economic independence and power to effect significant changes.

The first step toward ensuring a better distribution of legal services is to simplify currently outmoded statutory law so that rights and remedies can be easily enforced. Much of the complexity to which landlord-tenant law has fallen heir, for example, could be eliminated without jeopardizing the substantive rights of either group. Leases between landlords and tenants should be standardized so that enormous advantages do not accrue to the party who is favored by market forces and has been able to employ the cleverest lawyer. Similarly, procedures should be changed by state legislatures so that most wills could be completed by laymen using standardized forms; administrative law should be rewritten with the non-lawyer in mind so as to enable laymen to proceed pro se before most commissions, including liquor control commissions, unemployment compensation commissions and zoning boards; the courts should be taken out of the business of approving simple alterations of legal status such as divorces, separations, changes of names, and adoptions, and replaced by state-wide boards set up to expedite such proceedings.

Concurrent with this effort to simplify and demystify the substantive and procedural aspects of the law, but independently of it, the bar and the courts should re-examine their position on unauthorized practice. Despite mounting criticism of the legal profession's failure to provide legal services to all members of society at reasonable prices, there has thus far been little pressure on the bar to relinquish tasks

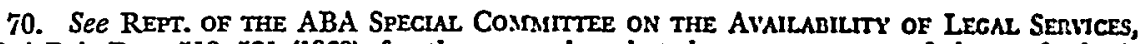
93 A.B.A. Rep. 518, 521 (1968), for the suggestion that the present scope of the profession's monopoly claim should be preserved intact but that the profession should regard its clients as consumers and its services as commodities-available at a prioe and quality, and in a form, attractive to the consuming market. This suggestion rould be acceptable to critics such as Carlin, but as this Note attempts to show, a change of the type indieated is offensive to professionalism in theory and has very little chance, as a practical matter, of being adopted by the legal profession. Schuckman, supra note 19, at 258. 
which do not require the skill of a lawyer. In part, this is a manifestation of the widely-held notion, shared by critics such as Carlin, that professionalism is an answer to all sorts of problems. ${ }^{71}$ To the extent that the bar, with the support of the courts, refuses to allow experimentation by lay groups that attempt to serve society in areas that the profession has served only sporadically, this notion tends to be self-fulfilling.

Many state courts attempt to use vague definitions of "the practice of law" to map out those areas which are exclusively for professionals, ${ }^{72}$ and which may be reclaimed from non-professionals through unauthorized practice suits. ${ }^{73}$

Other courts have resisted the sterility of definitions and have adopted various tests such as the "incidental test" which allows legal advice to be given and legal instruments to be prepared by non-lawyers if the work done is "proper[ly] incident" to a regular course of business.74 The incidental test has been restricted by courts in a few states so that it protects lay activity only insofar as it is not compensated. ${ }^{75}$ The Code of Professional Responsibility suggests a further test that can be employed by the courts:

71. Writers as diverse Tawney, Durkheim, and Brandeis have presaged the Bar's response to contemporary criticism by regarding "professionalism" as a cure for all sorts of difficult ailments. E. DURKheim, Professional EThics and GiviL Morals 29 (Cornclia Brookfield trans. 1957); R. TAwNEY, THE Acquisitive Society, Chapt. 7, IndusinY As A Profession (1920); L. Brandeis, Business-A Profession 12 (1914). For the moment at least, society-and the professions themselves-appear to have fallen prey to the appeal of professionalism without giving critical attention to the limitations as well as to the advantages of the professional model. Wilensky, The Professionalization of Everyonct, 70 AM. J. OF Soc. 137 (1964).

72. Arizona State Bar v. Arizona Land Title and Trust Co., 90 Ariz. 76, 366 P.2d 1 (1961), supp. 91 Ariz. 293, 371 P.2d 1020 (1962) (the practice of law consists of "those acts, whether performed in court or in the law office, which lawyers have customarily carrical on from day to day through the centuries"); State Bar Ass'n v. Connecticut Bank and Trust Co., 145 Conn. 222, 140 A.2d 863, 870 (1938) (acts which are "commonly understood to be the practice of law'); Opinion of the Justice, 289 Mass. 607, 194 N.E. 313 (1985) (the "customary functions of an attorney").

73. The bar has justified its unauthorized practice campaign as follows:

The unauthorized practitioner has neither the extensive legal cducation nor the train. ing of a lawyer. Furthermore, he is not subject to the same high standards of conduct as those to which lawyers must adhere. In addition, he has not met those stanclards of competence set by the state which authorized a lawyer to practice law. Thereforc, persons who engage in the unauthorized practice of law do not perform a service for the public; rather, their activities constitute a disservice both to their clients and to the public at large.

E. Stason, Unauthorized Practice Source Book, Foreword at iii (1961 ed.). It should be apparent that such a statement is totally meaningless without a prior determination of what constitutes the practice of law.

74. See, e.g., Creekmore v. Dzard, 236 Ark. 558, 356 S.W.2d 419 (1968); Cooperman v. West Coast Tile Co., 75 So. $2 d 818$ (Fla. 1954).

75. See, e.g., Kentucky State Bar Ass'n v. First Federal Savings and Loan Ass'n, 842 S.W.2d 397 (Ky. 1960); Conway-Bogue Realty Investment Co. v. Denver Bar Ass'n, 185 Colo. 398, 312 P.2d 998 (1957). 
$[T]$ he practice of law relates to the rendition of services for others that call for the professional judgment of a lawyer. The essence of the professional judgment of a lawyer is his educated ability to relate the general body and philosophy of law to a specific legal problem .... Where this professional judgment is not involved, non-lawyers ... may engage in occupations that require a special knowledge of law in certain areas. ${ }^{70}$

The problem with an approach to unauthorized practice based on the various definitions or tests that have been employed or proposed is that they only indirectly, if at all, reflect the rationale for licensed professional monopolies. ${ }^{77}$ The exclusion of laymen from the performance of certain work tasks can only be justified to the extent that a valid public interest is thereby served. ${ }^{78}$ Where the overriding public interest in the area of legal services-competent representation at reasonable pricescannot be secured by a professional monopoly, and is indeed hindered by such a monopoly, the only justification for the monopoly disappears.

To protect the public from the negligence and/or lack of training of lawyers and laymen engaged in providing legal services, courts and legislatures should require practitioners to make readily available to prospective clients complete and accurate information regarding their educational background and training. With this information at their disposal, clients should be allowed to hire a representative from among the wide range-in terms of skill and cost-available. The disciplinary mechanisms of the market would be adequate to punish mild deficiencies in service; the courts should stand ready to punish more serious forms of misconduct.

76. ABA CODE, EC 3-5, at 46. The phrase "professional judgment" provides an uncertain test, if indeed it is a test at all. The illusory content of the phrase is indieated by the following attempted justification for the limitation on the practice of law by lasmen:

Since the practice of law is, in the public interest, forbidden to anyone who has not

demonstrated the requisite competence and integrity, by meeting requirements for a

law license, lawyers have a monopoly in the rendition of legal services. The cxistence

of this monopoly in the important area of legal services, together with the fact that

the practice of law is a profession, dictate that the directives in the proposed Code be

based upon serving the public interest. Since the public interest is served by forbidding

laymen to practice law, it is against the public interest for lawyers to aid or encourage

Iaymen to practice law.

Sutton, The Impact of the Code of Professional Responsibility upon the Unauthorized Practice of Law, 48 N. Car. L. Rev. 633, 636-37 (1969).

Since the Code of Professional Responsibility does not purport to regulate the conduct of non-lawyers, it is directly relevant here only insofar as it encourages or requires certain conduct of lawyers in the area of unauthorized practice. Canon 3 is the principal statement in the Code on unauthorized practice: "A Lawjer Should Assist in Preventing the Unauthorized Practice of Law," ABA CODE, CANON 3, at 45.

77. They do, however, reflect very nicely the "interests" of the profession. See Johnstone, The Unauthorized Practice Controversy, A Struggle Among Power Groups, 4 KAN. L.

REv. 1 (1955). $66,82-83(1965)$. 
Meanwhile, the law schools have a responsibility to structure their curricula so as to reflect the skill requirements of lawyers in widely different types of practice. ${ }^{70}$ The amount of education required for all lawyers has increased substantially since the 1920 's ${ }^{80}$ despite the fact that the work tasks of lower echelon practitioners have often not increased in complexity-and those areas where there has been a spurt in actual complexity, such as consumer protection and welfare prob. lems, have not been dealt with in most law school curricula with emphasis proportionate to that increase. 81

Legal education should not be used as a means to maintain the discredited myth of a uniform bar with great mobility between various areas of practice, nor as a device to maintain competition at a "healthy" level by restricting entry into the profession and by fencing out actual and potential lay competition. ${ }^{82}$ This means that law schools should be innovative in experimenting with tracking systems involving specialization and varying lengths of required matriculation.

Finally, when exercising their inherent power to discipline members of the "professional" bar for deviance from the Code of Professional Responsibility, the only concern of the courts should be whether strict adherence to the canon in question is in the public interest. ${ }^{83}$ The interest of the profession, however defined, should be regarded as wholly extraneous to this determination..$^{84} \mathrm{~A}$ workable test that the courts could apply in exercising their disciplinary power would begin with a presumption of propriety for the activities of lawyers as long as those activities are not in conflict with state criminal prohibitions of general application. This presumption could be rebutted by clients or by local bar associations on a showing of substantial injury to the client because of the activity of his attorney. Substantial evidence of negli-

79. Overtraining of some lawyers given the tasks they will eventually perform secmis inevitable as long as the ABA clings to the notion that a general and uniform training is required before admission to the Bar. In many states, admissions standards are wholly within the control of the ABA. See, e.g., New Mexico, Rule 1, 22 (1958). Suits challenging the validity of special requirements for the practice of law on due process or equal protec. tion grounds have been uniformly unsuccessful. See In re Lockwood, 154 U.S. 116 (1893); Hennington v. State Board of Bar Examiners, 60 N.M. 393, 291 P.2d 1108 (1956).

80. Pincus, Reforming Legal Education, 53 A.B.A.J. 436 (1967).

81. Nader, Law Schools and Law Firms, Crumbling of the Old Order, TuE New Republic 20 (Oct. 11, 1969).

82. Johnstone, The Unauthorized Practice Controversy, A Struggle Among Powcr Groups, 4 KAN. L. REv. 1, 5 (1955).

83. See, e.g., In re Nevius, 174 Ohio St. 560, 191 N.E.2d 166 (1963); Gair v, Peck, 188 N.Y.S.2d 491, 160 N.E.2d 43 (1959), app. dis. 361 U.S. 374 (1960), mod. on other grounds, 6 N.Y.2d 983, 191 N.Y.S.2d 951, 161 N.Y.2d 736 (1959).

84. That the "professional interest" is not always so regarded is suggested by Smith, supra note 11, at 288. 
gence as well as evidence of positive wrongdoing would destroy the initial presumption.

Adoption of such a test by the courts would doubtlessly lead to a reduction in the importance of the profession's code of ethics as the lawyer's guide for behavior, but past experience with professional selfregulation indicates that this may very well be a desirable development. ${ }^{85}$ In the Code of Professional Responsibility, as in the legal profession's previous code of practice, self-regulation seems inevitably to lead to the compromise or subordination of the public interest to the short-range interest of the dominant segments of the profession.

But the courts' willingness to interpret the Code of Professional Responsibility liberally when called upon to deal with specific charges of attorney misconduct should not lull courts and legislatures into adopting the Code as written. ${ }^{80}$ Although getting local bar associations to agree to specific changes in the Code is likely to be difficult, the defects noted earlier, especially the insufficient allowance for variable conditions of practice, should be remedied before it is adopted in the various states so as to obviate its probable chilling effect on socially desirable conduct. The Code is likely to have such a chilling effect despite the willingness of the courts to assume a more active role in the disciplinary process. A court's willingness to use an ad hoc balancing test to determine propriety may make many lawyers timid, especially if they fear that, out of habit, courts will inevitably think in terms of uniform prohibitions.

Far from being the key to the crisis in legal services, "unethical" conduct among solo practitioners is but one manifestation of a professional claim gone awry. To the extent that the Code of Professional Responsibility expresses the bar's belief that its responsibility to society can be met by enforcing ethical standards in the profession as presently structured, it rests on either a delusion or a deliberate avoidance of the basic problems. The crisis in legal services can be met only by a bold reassessment of received notions of professionalism.

85. W. Gelihorn, Indindual Freedosr aNd Governarental Restrantis 105-151 (1950).

86. ABA President Bernard Segal has appointed a nine-member committee to spur carly adoption of the Code of Professional Responsibility by the states. The procedures by which the states adopt codes of legal ethics vary. In some states, favorable action by the state bar association is all that is necessary to secure adoption. But in the majority of jurisdictions, formal action by the state Supreme Court or the state legislature is required. It is probable that the Code may be regarded as persuasive authority in some states withoul formal approval. 